\title{
Diel feeding pattern and diet of rough scad Trachurus lathami Nichols, 1920 (Carangidae) from the Southwestern Atlantic
}

\author{
Maria Raquel de Carvalho and Lucy Satiko Hashimoto Soares
}

Diel changes in feeding activity and dietary composition of the rough scad Trachurus lathami were investigated through the analysis of stomach contents of 307 fish sampled over a 24 -h period on the continental shelf off Ubatuba $\left(23^{\circ} 35^{\prime} \mathrm{S} 45^{\circ} \mathrm{W}\right)$. Stomach contents were analyzed by frequency of occurrence $(\mathrm{O} \%)$, percent number $(\mathrm{N} \%)$, percent mass $(\mathrm{M} \%)$, and feeding index $(\mathrm{FI} \%=\mathrm{O} \% * \mathrm{M} \%)$. Rough scad fed on mollusks (Gastropoda, Crepidula sp.), crustacean (Ostracoda, Copepoda, decapod larvae), chaetognat and teleostean fish. The main items were calanoid copepods (Eucalanus sp. and Centropages sp.). According to the analysis of the stomach fullness and prey digestion, T. lathami is both a diurnal and nocturnal feeder, showing some seasonal variation in feeding time. According to the Chronobiology concept, it was raised the hypothesis of circadian rhythm in feeding of this fish, probably synchronized by light/dark cycle.

O estudo da dieta e do padrão diário e sazonal de atividade alimentar do chicharro Trachurus lathami foi realizado através de análises dos conteúdos estomacais de 307 peixes amostrados em estações fixas de coleta de 24 horas na plataforma continental ao largo de Ubatuba $\left(23^{\circ} 35^{\prime} \mathrm{S} 45^{\circ} \mathrm{W}\right)$. Os conteúdos estomacais foram analisados através da freqüência numérica (N\%), massa porcentual (M\%) e freqüência de ocorrência $(\mathrm{O} \%)$ dos itens alimentares, e índice alimentar $(\mathrm{O} \% * \mathrm{M} \%)$. A espécie caracterizouse por ingerir principalmente copépodes calanóides (ex. Eucalanus sp. e Centropages sp.), além de outros crustáceos (Ostracoda, larva de decápodes), moluscos (Gastropoda: Crepidula sp.), quetognatos e peixes teleósteos. De acordo com o grau de repleção estomacal e grau de digestão das presas, T. lathami ingeriu alimento tanto na fase clara quanto na fase escura do dia, apresentando variação sazonal no horário de tomada de alimento. De acordo com os conceitos da Cronobiologia foi levantada a hipótese de ritmo circadiano na atividade alimentar, provavelmente sincronizado pelo ciclo claro/escuro.

Key words: Food Habits, Feeding Ecology, Stomach Contents, Rhythms, Southeast Brazil.

\section{Introduction}

The critical and limiting resources for all animals are food and time. Food provides energy and nutrients for reproduction, and to develop, maintain, and protect the somatic body. Time is necessary for foraging, as well as for other activities, such as resting and reproduction (Wootton, 1990). According to chronobiologists, the majority of organisms present a circadian rhythm in their activities and this organization is the result of an evolutionary process that expresses a synchronicity among geophysical, environmental and biological events (Marques \& Menna-Barreto, 2003). Among marine, estuarine, and freshwater fishes, there are several records of feeding activity with circadian rhythm (see Neilson \& Perry, 1990; Boujard \& Leatherland, 1992, Sánchez-Vázquez et al., 1997, Gerkema et al., 2000).

Studies on diel feeding in the natural environment are ba- sic tools to understand the autoecology of fish species. And studies on diet composition may contribute to clarify preypredator relationships, and to elaborate trophic models for the assessment of stocks (Christensen \& Pauly, 1992).

Most species of Trachurus are widely distributed in both temperate and tropical coastal waters. Fifteen species are recognized (Suda et al., 1995). Only Trachurus lathami Nichols 1920 occurs in the south-western Atlantic from the Gulf of Maine (United States of America) down to the north of Argentina. It is a demersal-pelagic species, with maximum size about $40 \mathrm{~cm}$ of length and $0.5 \mathrm{~kg}$ of mass (Menezes \& Figueiredo, 1980), occurring in waters from 50 to $100 \mathrm{~m}$ in depth, at temperatures between $15^{\circ}$ and $17^{\circ} \mathrm{C}$ and salinity between 35.5 and 35.8 (Saccardo \& Katsuragawa, 1995; Mello et al., 1992).

Trachurus lathami is an abundant species on the southeastern Brazilian coast and represents a potential fishing resource (Saccardo \& Katsuragawa, 1995). 
Considering that there are few studies on diet composition of T. lathami (Pedreira, 1997; Crispino, 1995) and there are no studies about diel feeding of this species, we proposed to identify its pattern of daily feeding activity, and to describe the variation of its diet composition during the course of the day.

Study area. The study site is located on the continental shelf of the coastal system off Ubatuba (23ํำ $\left.35^{\prime} \mathrm{S}, 45^{\circ} 00^{\prime} \mathrm{W}\right)$, Brazil, southwestern Atlantic (Fig. 1).

Different water masses are present in this area during summer and winter. During summer, there is a two-layer vertical stratification due to the seasonal thermocline: the upper layer consists of warmer and less saline Coastal Water $-\mathrm{CW}(\mathrm{T}=22-$ $\left.24^{\circ} \mathrm{C} ; \mathrm{S}=35-35.4\right)$ and the lower of colder South Atlantic Central Water-SACW $\left(\mathrm{T}=14-15^{\circ} \mathrm{C} ; \mathrm{S}=35.6-35.8\right)$. During the winter, only Coastal Water is present on the inner shelf (Castro \& Miranda, 1998).

\section{Materials and Methods}

Sampling. Rough scad were sampled during the periods 2224 July 1988 and 4-6 December 1988 on the continental shelf off Ubatuba, São Paulo State, Brazil (Fig. 1). On each cruise, samples were collected in two consecutive 24-hour periods at 3-hour intervals, through $30 \mathrm{~min}$ trawls.

From the total catch, a sample of at least 30 specimens were randomly separated for biological analysis, size considered suitable for this type of study (eg. Livingston, 1982); all available individuals were collected from the small samples. A total of 307 stomachs were considered in this study (Table 1).

The specimens were frozen, and the total length and total mass of each individual were measured in the laboratory. The stomachs were removed and preserved in $10 \%$ buffered formalin solution.

Regional samples of this species are deposited in Museu

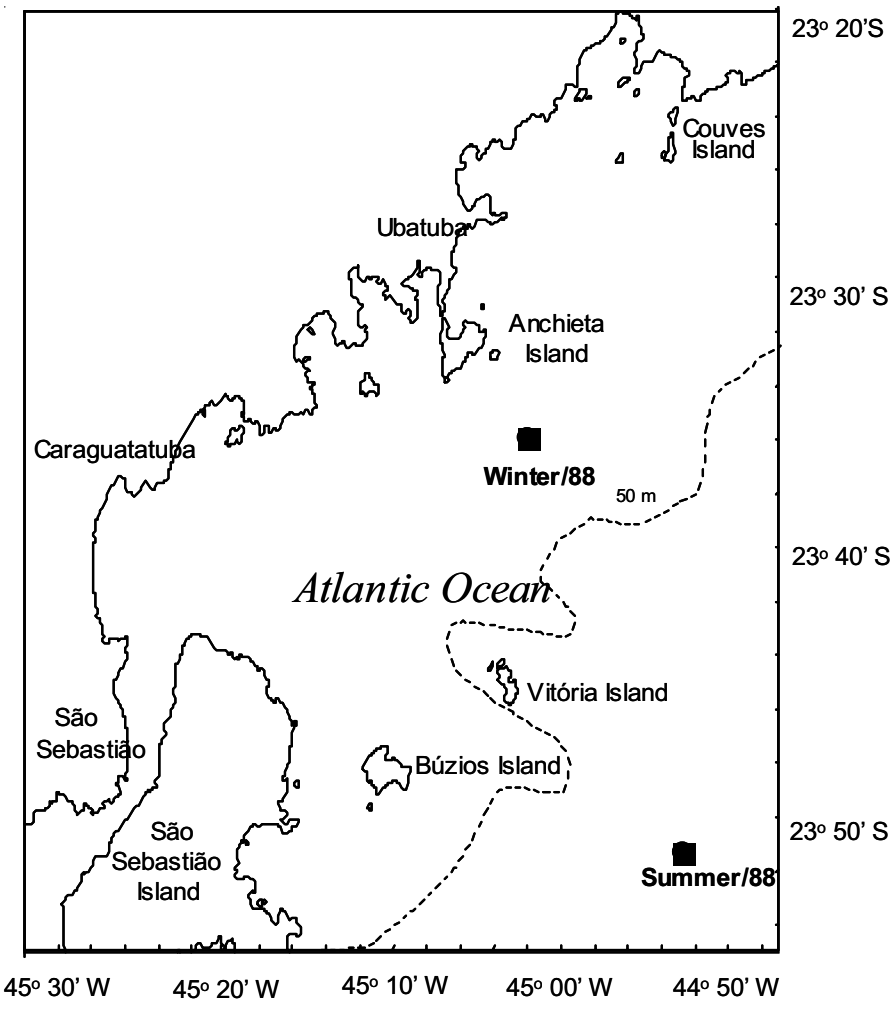

Fig. 1. Sampling area on the southeastern Brazilian shelf and the trawl stations location.

de Zoologia da Universidade de São Paulo (MZUSP 65886, MZUSP 65888, MZUSP 25887).

Laboratory methods. A fullness level was assigned for each stomach: empty, half full and full (Hyslop, 1980). The stomach content was sorted taxonomically and the degree of digestion (1-fresh prey; 2- partially digested prey; 3- digested

Table 1. Sampling information for Trachurus lathami from Brazilian shelf off Ubatuba.

\begin{tabular}{|c|c|c|c|c|c|c|c|}
\hline Winter & time (h) & phase & $\begin{array}{c}\text { stomach } \\
(\mathrm{n})\end{array}$ & size range $(\mathrm{mm})$ & $\begin{array}{c}<115 \mathrm{~mm} \\
\text { (n) }\end{array}$ & $\begin{array}{c}>115 \mathrm{~mm} \\
\text { (n) }\end{array}$ & mean mass $(\mathrm{g})$ \\
\hline $22 / 07 / 88$ & $15: 13$ to $15: 43$ & afternoon & 17 & $104-128$ & 8 & 9 & 16.69 \\
\hline $22 / 07 / 88$ & $18: 17$ to $22: 15$ & night & 37 & $110-157$ & 3 & 34 & 22.31 \\
\hline $23 / 07 / 88$ & $00: 10$ to $00: 40$ & night & 6 & $111-136$ & 1 & 5 & 16.74 \\
\hline $23 / 07 / 88$ & $10: 46$ to $11: 16$ & morning & 26 & $104-153$ & 5 & 21 & 17.99 \\
\hline $23 / 07 / 88$ & $15: 23$ to $15: 53$ & afternoon & 2 & $112-114$ & 2 & 0 & 14.25 \\
\hline Total & & & 88 & 104-157 & 19 & 69 & 17.60 \\
\hline Summer & time $(\mathrm{h})$ & phase & $\begin{array}{c}\text { stomach } \\
(\mathrm{n})\end{array}$ & size range $(\mathrm{mm})$ & $\begin{array}{l}<115 \mathrm{~mm} \\
\text { (n) }\end{array}$ & $\begin{array}{c}>115 \mathrm{~mm} \\
\text { (n) }\end{array}$ & mean mass $(\mathrm{g})$ \\
\hline $12 / 4 / 1988$ & $14: 06$ to $17: 37$ & afternoon & 36 & $53-92$ & 36 & 0 & 3.11 \\
\hline $12 / 4 / 1988$ & $23: 04$ to $23: 34$ & night & 1 & 149 & 0 & 1 & 31.80 \\
\hline $12 / 5 / 1988$ & $02: 43$ to $03: 13$ & night & 5 & $65-155$ & 1 & 4 & 22.12 \\
\hline $12 / 5 / 1988$ & $05: 11$ to $05: 41$ & dawn & 29 & $79-175$ & 4 & 25 & 30.07 \\
\hline $12 / 5 / 1988$ & $08: 55$ to $11: 40$ & morning & 35 & $56-154$ & 33 & 2 & 4.93 \\
\hline $12 / 5 / 1988$ & $15: 05$ to $17: 39$ & afternoon & 37 & $54-167$ & 17 & 20 & 22.20 \\
\hline $12 / 5 / 1988$ & $20: 01$ to $20: 31$ & night & 10 & $56-168$ & 3 & 7 & 32.68 \\
\hline $12 / 6 / 1988$ & $02: 05$ to $02: 35$ & night & 9 & $53-170$ & 5 & 4 & 15.99 \\
\hline $12 / 6 / 1988$ & $05: 13$ to $05: 43$ & dawn & 28 & $55-170$ & 15 & 13 & 19.56 \\
\hline $12 / 6 / 1988$ & $08: 00$ to $08: 30$ & morning & 29 & $48-97$ & 29 & 0 & 3.38 \\
\hline Total & & & 219 & $53-175$ & 143 & 76 & 18.58 \\
\hline
\end{tabular}


prey) was assigned for individual items, according to Soares $\&$ Apelbaum (1994). The state of digestion of the total stomach content was assigned based on the proportion of prey in a particular state in the content: fresh, more than $75 \%$ of the prey in a fresh state; partially digested, $25-75 \%$ of fresh content and digested, less than $25 \%$ of fresh prey.

Data analysis. Diel feeding activity was analyzed according to data on stomach's fullness levels (\%), stomach index of fullness $(\mathrm{BM} \%=$ mass of the stomach content $\mathrm{X}$ mass of the fish $^{-1}$ X 100), state of digestion of the stomach content (\%), and number and frequency of fresh prey.

The samples were joined into a single 24-hour cycle per sampling period; the midpoint of each hauling period was used as a reference point in time. Sampling times that were less than half an hour apart were brought together into a single sample, and the midpoints averaged (Table 1). Variations in the $\mathrm{BM} \%$ and number of fresh prey between sampling periods of the day were tested by Kruskall-Wallis' nonparametric test variance analysis (Zar, 1996) to assess the influence of the sampling time on feeding activity.

The stomach contents were analyzed using: frequency of occurrence $(\mathrm{O} \%)$, percent number $(\mathrm{N} \%)$, percent mass $(\mathrm{M} \%)$ (Hyslop, 1980), and a feeding index (FI\% $=\mathrm{O} \% * \mathrm{M} \%)$ (Kawakami and Vazzoler, 1980). Cluster analysis (UPGMA method), using Shoener's percent similarity index (PS), was used to analyze the diel changes in prey composition (Magurran, 1988; Linton et al., 1981). Values of PS vary from 0, when no food is shared, to 1 , when there are the same proportional food resources. As suggested in literature (eg. Wallace, 1981; Cabral, 2000 ) values $P S \geq 60 \%$ should be considered similar.

\section{Results}

Oceanographic conditions. In this study, during the winter, water temperature ranged from 19 to $21^{\circ} \mathrm{C}$ and salinity from 32 to 35 , presenting a homogeneous profile throughout the day. In the summer, two water masses were present, one of them with temperatures between 21 and $23^{\circ} \mathrm{C}$ and salinity between 35.3 and 35.9 , and the other with temperatures between 15 and $19^{\circ} \mathrm{C}$ and salinity between 35.5 and 36 . The temperature profiles are shown in Fig. 2.

Diel feeding activity. The stomach's fullness levels and index of fullness showed the same diel pattern during the winter and summer (Figs. 3-4). Full stomachs occurred in the afternoon and at night. Empty stomachs occurred only in the summer, in the early morning and at dawn. Data on index of fullness revealed a pattern of daytime feeding, attaining maximum values during the afternoon in the winter (Kruskall-Wallis test: $\mathrm{c}^{2}=47,09$; $\mathrm{P}<0.0001$ ) and summer (Kruskall-Wallis test: $\mathrm{c}^{2}=138.93 ; \mathrm{P}=0$ ).

The index of fullness presented the same tendency along the day, in winter and summer, when fishes were divided in adults ( $\geq 115 \mathrm{~mm})$ and juvenile $(<115 \mathrm{~mm})$, following the estimative of the size of first maturity (Saccardo \& Katsuragawa, 1995) (Fig. 5).

The proportion of stomachs containing fresh prey was highest in the afternoon (15:33h) and at night (18:32h) in the winter. During the summer, stomachs with fresh or partially digested prey were highest at afternoon (15:20h, 17:23h) and at night (20:16h) just stomachs with partially digested prey occurred (Fig. 6).

Diet. The diet of T. lathami was composed of Mollusca, Crustacea, Chaetognatha, and Teleostei fish (eggs and larvae.

Among Arthropoda there was a greater abundance of Crustacea, represented by Ostracoda and Copepoda (Tab. 2).

The diet composition was similar over the feeding activity time (afternoon and night) during the winter and summer, and consisted mainly of calanoid copepods (Eucalanus sp. and Centropages sp.) and decapod larvae (Tab. 3).

Two similar groups of length class were detected based on diet composition. Specimens of the classes of 50 to $90 \mathrm{~mm}$ presented similar diet composition, mainly cumaceans, and the classes of 100 to $130 \mathrm{~mm}$ ingested essentially calanoid copepods (Tab. 4).
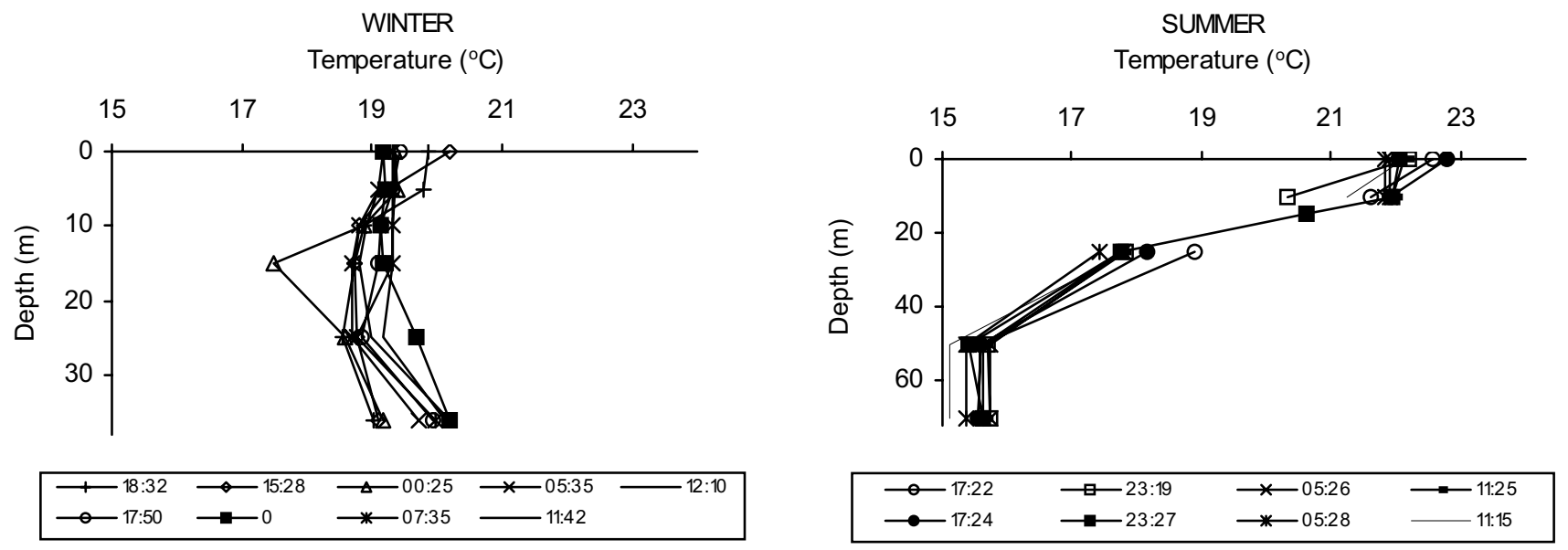

Fig. 2. Fluctuation of water temperature at different times of the day, in winter $\left(23^{\circ} 35.6^{\prime} \mathrm{S} / 44^{\circ} 59^{\prime} \mathrm{W}\right)$ and summer $\left(23^{\circ} 51.3^{\prime} \mathrm{S} /\right.$ $\left.44^{\circ} 47.6^{\prime} \mathrm{W}\right) 1988$, on the shelf off Ubatuba. 
Table 2. Frequency of occurency (O\%), percent mass (M\%), and feeding index (FI\%) of food items of Trachurus lathami collected in winter and summer from Brazilian shelf off Ubatuba.

\begin{tabular}{|c|c|c|c|c|c|c|}
\hline \multirow[b]{2}{*}{ Food items } & \multicolumn{3}{|c|}{ Winter $(\mathrm{n}=88)$} & \multicolumn{3}{|c|}{ Summer $(n=219)$} \\
\hline & $\mathrm{O} \%$ & $\mathrm{M} \%$ & $\mathrm{FI} \%$ & $\mathrm{O} \%$ & $\mathrm{M} \%$ & FI\% \\
\hline Gastropoda & 22.730 & 0.179 & 0.558 & & & \\
\hline Crustacea & 48.860 & 23.034 & & 67.480 & 34.522 & \\
\hline Ostracoda & 15.910 & 0.179 & 0.552 & 18.400 & 0.334 & 2.282 \\
\hline Copepoda & 48.860 & 16.167 & & & & \\
\hline Calanoides sp. & 29.550 & 0.974 & 3.681 & 7.980 & 0.223 & 1.224 \\
\hline Calanopia americana & 2.270 & 0.038 & 0.028 & 0.610 & 0.008 & 0.071 \\
\hline Candacia sp. & 3.410 & 0.090 & 0.050 & 11.040 & 0.485 & 3.073 \\
\hline Centropages sp. & 38.640 & 3.228 & 17.984 & & & \\
\hline Ctenocalanus sp. & 2.270 & 0.013 & 0.009 & 0.610 & 0.008 & 0.002 \\
\hline Eucalanus sp. & 32.950 & 5.840 & 26.400 & 14.720 & 12.160 & 83.218 \\
\hline Paracalanus sp. & 3.410 & 0.038 & 0.042 & 1.230 & 0.645 & 0.326 \\
\hline Temora stylifera & 43.180 & 2.729 & 12.450 & 14.110 & 0.183 & 1.004 \\
\hline Hemicyclops sp. & 1.140 & 0.013 & 0.005 & & & \\
\hline Corycaeus sp. & 31.820 & 0.167 & 0.780 & 5.520 & 0.048 & 0.152 \\
\hline Oncaea sp. & 25.000 & 0.128 & 0.394 & 8.590 & 0.088 & 0.277 \\
\hline Decapoda (larvas) & 30.680 & 5.790 & 35.146 & 7.980 & 0.875 & 2.920 \\
\hline Luciferidae & 15.910 & 0.525 & 1.131 & & & \\
\hline Brachyura (zoea) & 20.450 & 0.167 & 0.540 & 1.230 & 0.024 & 0.012 \\
\hline Brachyura (megalopa) & 2.270 & 0.064 & 0.047 & 2.450 & 0.231 & 1.353 \\
\hline Mysidacea & 1.140 & 0.013 & 0.005 & & & \\
\hline Anchistylis sp. & & & & 38.650 & 0.159 & 2.845 \\
\hline Campylaspis sp. & & & & 0.610 & 0.008 & 0.002 \\
\hline Cyclaspsis sp. & 2.270 & 0.013 & 0.060 & & & \\
\hline Diastylis sp. & 2.270 & 0.013 & 0.060 & 13.500 & 0.088 & 1.056 \\
\hline Cyclaspis sp. & & & & 1.840 & 0.024 & 0.089 \\
\hline Chaetognatha & & & & 1.230 & 0.048 & 0.024 \\
\hline Teleostei & 2.270 & 0.282 & 0.096 & 0.610 & 0.064 & \\
\hline teleostean egg & 3.410 & 0.038 & 0.017 & & & \\
\hline crustacean egg & 1.140 & 0.013 & 0.003 & 3.070 & 0.024 & 0.030 \\
\hline
\end{tabular}

\section{Discussion}

Trachurus lathami presented distinct phases of feeding and nonfeeding time during the 24-hour period, suggesting a circadian rhythm in feeding activity. Evening and nocturnal feeding activity were observed. We can say that even in the summer and in the winter, the feeding activity occurred, mainly, at afternoon and night phases. This similar result can be explained by the fact of the distinct points where the sample was collected ( $38 \mathrm{~m}$ in winter and $72 \mathrm{~m}$ in summer) were located in an intermediate area. This area presents different oceanographic conditions (Castro \& Miranda, 1998), but this species in large schools can occupy all of this area, including the different points cited (Almeida, 2001; Saccardo \& Katsuragawa, 1995).

The majority of the fish known as "horse-mackerel" (Trachurus spp.) present diurnal feeding habits (Shuntov, 1969; Pillar \& Barange, 1998). Daily variation in feeding activity is often recorded in other carangids, and they usually present a pattern of feeding activity with greater intensity around twilight (Danemann, 1993; Helmer et al., 1995).
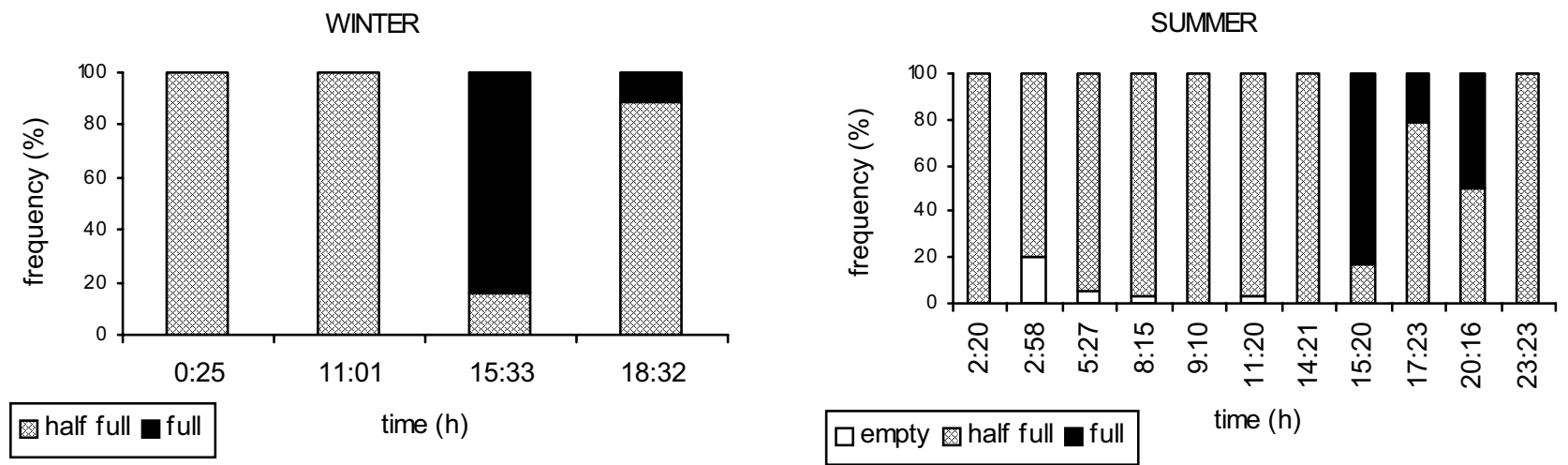

Fig. 3. Proportion of the stomach fullness levels of Trachurus lathami from Ubatuba shelf by sampling period in winter (22-24/ $\left.07 / 1988-23^{\circ} 35.6^{\prime} \mathrm{S} / 44^{\circ} 59^{\prime} \mathrm{W}\right)$ and summer $\left(04-06 / 12 / 1988-23^{\circ} 51.3^{\prime} \mathrm{S} / 44^{\circ} 47.6^{\prime} \mathrm{W}\right)$. 
Table 3. Feeding index of food items of Trachurus lathami collected in winter and summer from Brazilian shelf off Ubatuba. $*$ and $* *$ Percent similarity index $(\mathrm{PS})>60 \%$.

\begin{tabular}{|c|c|c|c|c|c|c|}
\hline \multirow[b]{2}{*}{ Food items } & \multicolumn{2}{|c|}{ Winter $(\mathrm{n}=88)$} & \multicolumn{4}{|c|}{ Summer $(n=219)$} \\
\hline & morning & afternoon* & night* & morning & afternoon** & night** \\
\hline Gastropoda & 40.820 & 0.070 & 0.640 & & & \\
\hline Ostracoda & & 0.670 & 0.160 & 11.760 & 3.370 & \\
\hline Calanoides sp. & & 3.220 & 5.400 & & 0.820 & 1.970 \\
\hline Calanopia americana & & 0.040 & & & & 0.200 \\
\hline Candacia sp. & 3.060 & & 0.110 & & 2.650 & 3.940 \\
\hline Centropages sp. & & 17.550 & 20.190 & & & \\
\hline Ctenocalanus sp. & & 0.010 & & & 0.001 & \\
\hline Eucalanus sp. & & 23.580 & 37.140 & 23.530 & 84.720 & 83.270 \\
\hline Paracalanus sp. & & 0.060 & & & 0.530 & \\
\hline Temora stylifera & 24.490 & 7.780 & 27.990 & 0.980 & 1.360 & 0.390 \\
\hline Hemicyclops sp. & & 0.010 & & & & \\
\hline Corycaeus sp. & & 0.780 & 0.800 & & 0.130 & 0.200 \\
\hline Oncaea sp. & 30.610 & 0.090 & 0.270 & 0.980 & 0.420 & \\
\hline Decapoda (larvas) & 1.020 & 44.250 & 5.230 & & 3.780 & 1.570 \\
\hline Luciferidae & & 1.050 & 1.470 & & & \\
\hline Brachyura (zoea) & & 0.590 & 0.400 & & 0.020 & \\
\hline Brachyura (megalopa) & & 0.060 & & & 0.110 & 3.540 \\
\hline Mysidacea & & 0.010 & & & & \\
\hline Hyperiidae & & 0.01 & 0.03 & & & \\
\hline Gammaroidea & & 0.07 & 0.01 & & 0.01 & \\
\hline Isopoda & & & & & 0.001 & \\
\hline Tanaidacea & & & & 0.98 & & \\
\hline Anchistylis sp. & & & & 43.140 & 1.750 & 2.950 \\
\hline Campylaspis sp. & & & & & 0.001 & \\
\hline Cyclaspsis sp. & & & 0.030 & 0.980 & 0.001 & 0.200 \\
\hline Diastylis sp. & & & 0.030 & 17.650 & 0.210 & 1.770 \\
\hline Cyclaspis sp. & & & & 0.98 & 0.001 & 0.2 \\
\hline Chaetognatha & & & & & 0.040 & \\
\hline Teleostei & & 0.110 & 0.050 & & 0.030 & \\
\hline teleostean egg & & 0.010 & 0.050 & & & \\
\hline crustacean egg & & & 0.010 & & 0.050 & \\
\hline P.S & $* 60 \%$ & & & $* * 91 \%$ & & \\
\hline
\end{tabular}

The circadian rhythms in fish may be associated with various factors such as light, temperature, salinity, and availability of prey or with association of these factors. The light has been suggested as a strong and universal influence, acting powerfully in the synchronization of these physiological and behavioral rhythms (McFarland, 1986; Boujard \& Leatherland, 1992; Marques \& Menna-Barreto, 2003). Diurnal and nocturnal feeding activity must be related to the difference in the intensity of light, which brings alternation in the period of time of the light and dark phases of the day (Boujard \& Leatherland, 1992).

Hunter (1968) suggested, however, that with adequate light, as when there is a full moon, some fish are able to feed at the surface at night. In the present study, data were collected during periods of the waxing or waning of the moon, therefore without interference of moonlight in the feeding activity of the
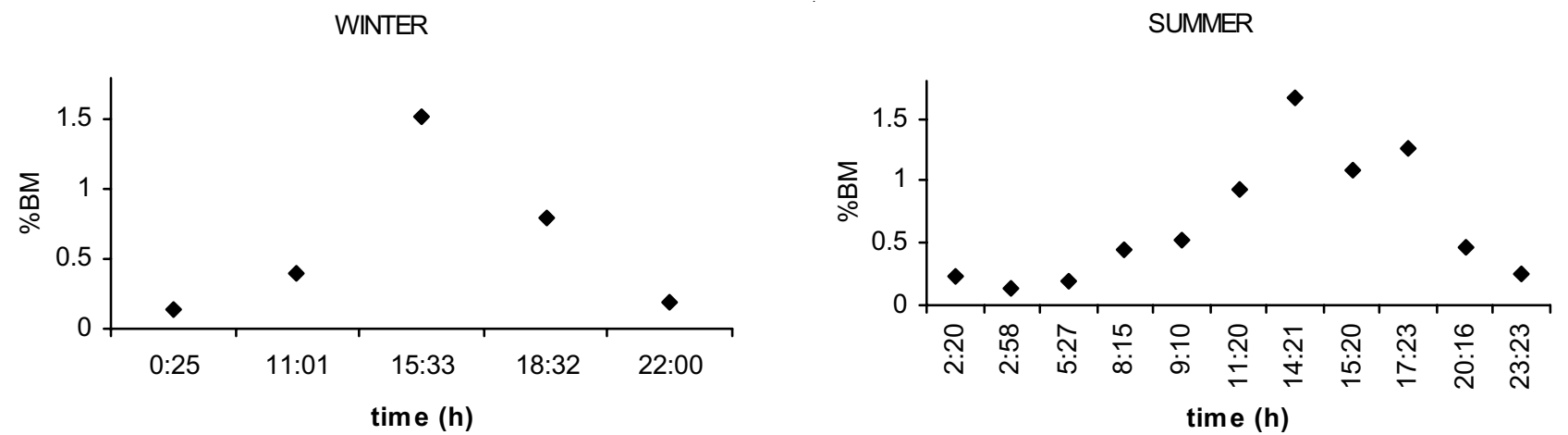

Fig. 4. Stomach index of fullness expressed as BM\% (mass of the stomach content $\mathrm{x}$ mass of the fish ${ }^{-1} \mathrm{x} 100$ ) of Trachurus

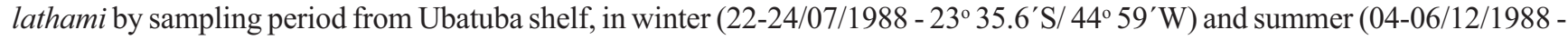
$\left.23^{\circ} 51.3^{\prime} \mathrm{S} / 44^{\circ} 47.6^{\prime} \mathrm{W}\right)$. 
Table 4. Diet composition of Trachurus lathami expressed by feeding index (FI\%) according of lenght classes (mm) of fish collected in winter and summer on Brazilian shelf off Ubatuba. * and ** Percent similarity index (PS) $>60 \%$.

\begin{tabular}{|c|c|c|c|c|c|c|c|c|c|c|c|c|}
\hline \multirow{2}{*}{$\frac{\text { Food items }}{\text { Mollusca }}$} & $50-60 *$ & $60-70^{*}$ & $70-80 *$ & $80-90 *$ & $90-100^{*}$ & $100-110^{* *}$ & $110-120 * *$ & $120-130^{* *}$ & $130-140 * *$ & $140-150$ & $150-160$ & $160-170$ \\
\hline & & & & & & & & & & & & \\
\hline Gastropoda & & & & & & 0.28 & 0.11 & 0.49 & 1.36 & 0.14 & & \\
\hline Ostracoda & 0.22 & 4.98 & 1.82 & 25.00 & 7.14 & 0.56 & 0.10 & 0.10 & 0.03 & 0.26 & 0.34 & 0.21 \\
\hline Calanoides sp. & & & 0.36 & & & 3.94 & 3.18 & 1.47 & 2.98 & 2.93 & 0.63 & 0.31 \\
\hline Calanopia americana & & & & & & & 0.00 & & & 0.00 & & 0.05 \\
\hline Candacia sp. & 1.99 & 0.06 & & & & 0.28 & 0.01 & 0.02 & 0.03 & 0.28 & 1.78 & 1.67 \\
\hline Centropages sp. & & & & & & 32.68 & 22.34 & 19.84 & 23.67 & 18.97 & & \\
\hline Ctenocalanus sp. & 0.22 & & & & & & 0.01 & & & 0.01 & & \\
\hline Eucalanus sp. & & 0.06 & 0.36 & 2.78 & & 43.38 & 32.37 & 29.64 & 36.84 & 36.15 & 91.66 & 41.78 \\
\hline Paracalanus sp. & & & & & & & 0.02 & 0.02 & & 0.91 & 0.96 & 49.61 \\
\hline Temora stylifera & 0.22 & 0.06 & 1.09 & & & 12.39 & 8.16 & 37.04 & 27.37 & 9.42 & 3.18 & 3.13 \\
\hline Hemicyclops sp. & & & & & & & 0.00 & & & 0.00 & & \\
\hline Corycaeus sp. & 0.22 & 0.51 & 0.73 & 2.78 & 14.29 & 4.23 & 1.96 & 3.72 & 5.19 & 1.87 & & 0.21 \\
\hline Oncaea sp. & 0.22 & 1.02 & & 2.78 & 7.14 & 0.28 & 0.17 & 1.91 & 1.30 & 0.34 & 0.02 & \\
\hline Decapoda (larvas) & 0.22 & 0.06 & 0.36 & & & 1.69 & 30.61 & 5.39 & 0.58 & 24.94 & 0.50 & 2.51 \\
\hline Luciferidae & & & & & & & 0.40 & 0.10 & 0.39 & 0.32 & & \\
\hline Brachyura (zoea) & 0.22 & & & & & 0.28 & 0.50 & 0.20 & 0.06 & 0.41 & & \\
\hline Brachyura (megalopa) & & & & & & & 0.00 & & & 0.02 & 0.08 & 0.05 \\
\hline Mysidacea & & & & & & & 0.00 & & & 0.00 & & \\
\hline Anchistylis sp. & 92.92 & 90.84 & 88.89 & 66.67 & 71.43 & & & & & 2.79 & 0.59 & 0.21 \\
\hline Cyclaspsis sp. & 0.44 & 0.23 & & & & & & & 0.03 & 0.01 & 0.02 & \\
\hline Diastylis sp. & 0.88 & 1.13 & 5.74 & & & & & & & 0.14 & 0.19 & \\
\hline Campylaspsis sp. & 0.22 & & & & & & & & & 0.00 & & \\
\hline Tanaidacea & & 0.06 & & & & & & & & 0.00 & & \\
\hline Isopoda & & & 0.55 & & & & & & & 0.01 & & \\
\hline Amphipoda & & 0.06 & & & & & & & & 0.01 & & 0.26 \\
\hline Hyperiidea & & & & & & & & 0.02 & 0.03 & 0.00 & & \\
\hline Gammaroidea & 0.22 & 0.06 & & & & & 0.01 & 0.02 & & 0.01 & & \\
\hline Chaetognatha & 0.22 & & & & & & 0.04 & & & 0.04 & 0.02 & \\
\hline Teleostei & 0.22 & & & & & & 0.00 & & & 0.01 & 0.02 & \\
\hline teleostean egg & & 0.06 & & & & & 0.00 & & 0.13 & 0.01 & & \\
\hline crustacean egg & 1.33 & 0.85 & 0.09 & & & & 0.00 & & & 0.02 & & \\
\hline $\mathrm{n}$ & 27 & 62 & 33 & 15 & 4 & 6 & 39 & 19 & 13 & 35 & 32 & 11 \\
\hline P.S & $* 73 \%$ & & & & & $* * 70 \%$ & & & & & & \\
\hline
\end{tabular}

fish. Fluctuations in temperature and salinity during the day were not reflected in the daily cycle. It may be conjectured, however, that the light, during the photoperiod must act as an abiotic factor responsible for the synchronization between the environmental events and the feeding activity of $T$. lathami. The vertical migration shown by the species, which migrates to the surface layer during the night and remains at the bottom during the morning (Saccardo, 1987), may also be synchronized by the cycle of availability of prey. Beyond this fact, the migration of prey may also occur in such a way as to synchronize it to the light/dark cycle (Neilson \& Perry, 1990). The feeding phase of T. lathami is the same of those that have been registered in the main catches of this species, denoting the higher vulnerability on these times (Almeida, 2001).
WINTER

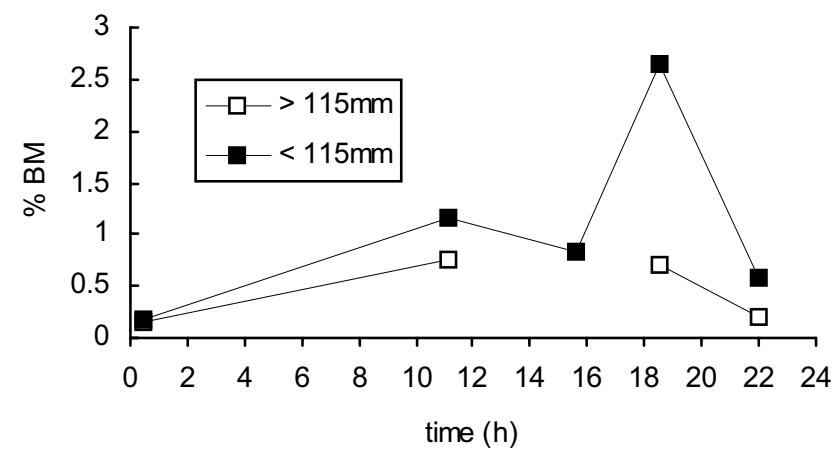

SUMMER

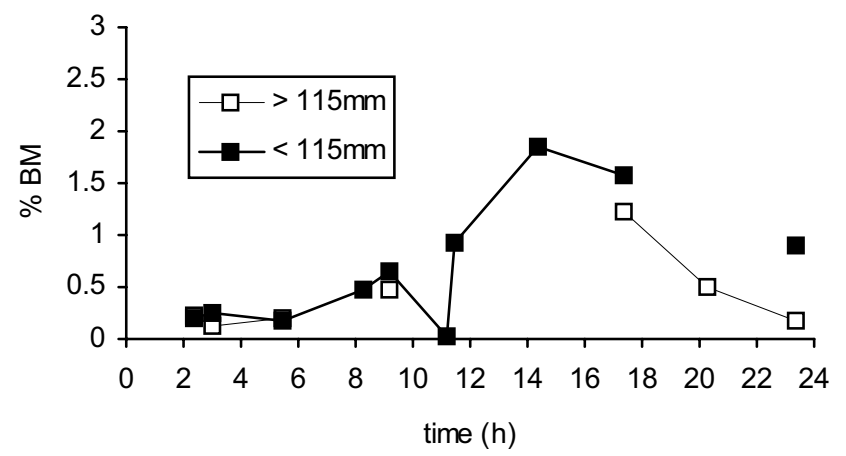

Fig. 5. Mean of stomach index of fullness expressed as BM\% (mass of the stomach content $x$ mass of the fish ${ }^{-1} \mathrm{x} 100$ ) of adult $(\geq 115 \mathrm{~mm})$ and juvenile $(<115 \mathrm{~mm})$ Trachurus lathami by sampling period from Ubatuba shelf, in winter and summer. 
Overall, the diet of T. lathami was similar in the two phases of feeding activity, being mainly composed of calanoid copepods, which are the most abundant copepod in the study area (Veja-Pérez, 1993). In relation to Eucalanidae copepods, they are abundant along the year (Hernandez, 1999; Oliveira, 1999), which might explain their occurrence over all the 24hours cycle, both in winter and in summer.

Difference as the occurrence of decapod larvae only at the twilight and nocturnal phases in the winter, for instance, may be related to the phase in the development of these organisms. In the case of the ingestion of cumaceans mainly in summer, it must be associated with their greater abundance in this season, related to the penetration of the cold water of the SACW (Santos, 1992). In the summer the penetration of the SACW leads to the nutrient enrichment of the euphotic zone water, causing an increase in the production of phytoplankton. This primary production sustains a larger biomass of herbivorous zooplankton and offers better conditions for the survival of fish larvae and benthic animals (Pires-Vanin \& Matsuura, 1993). Cumaceans present the same pattern of daily vertical migration (Santos \& Pires-Vanin, 1999) as T. lathami (Saccardo, 1987), moving upward during the night and descending during the morning. This co-existence explains the prey-predator relationship between cumaceans and T. lathami.

Trophic interactions are complex relationships that involve food, fish, predators, biological process and displacement in water (Manteifel et al., 1978). The vertical migration of many species of crustaceans is due to endogenous rhythm synchronized by light/dark cycle (Neilson \& Perry, 1990) that produces the synchronicity between the movement of the prey and predators.

We may point out that there are clear evidences of temporal organization in the feeding activity of T. lathami in the daily cycle. Based on the evening and nocturnal activity, we can suggest the hypothesis of a circadian rhythm for this species, synchronized by the light/dark cycle and/or by the cycle of availability of food. However, to know if this rhythm is endogenous or exogenous, free-running laboratory experiments are needed in order to study the origin of the rhythm. If this feeding rhythm would be detected in constant condi- tions, without any environmental cycle, it could be considered an endogenous rhythm, characterized by an anticipation of cyclic changes, if not, exogenous rhythm is related with a direct answer to an environmental cycle.

The results related with feeding activity pattern of this study can improve the fisheries resolutions for management of this increasing economical resource.

\section{Acknowledgements}

This work was part of M.R.C. Master thesis, supported by Fapesp (Fundação de Auxílio à Pesquisa do Estado de São Paulo) (Proc. 97/12628-0). L.S.H.S. was partially supported by grant of the CNPq (Conselho Nacional de Pesquisa) (Proc. 523249/96-9). We are grateful to the CIRM (Comissão Interministerial para Recursos do Mar) for financial support. Special thanks to Dr Tagea K. Björnberg for helping with identification of copepods.

\section{Literature Cited}

Almeida, C. R. T. 2001. Variações temporais na estrutura da comunidade de peixes demersais da plataforma continental de Ubatuba, SP. Unpublished Ph.D. Dissertation, Universidade de São Paulo, São Paulo. 85p.

Boujard, T. \& J. F. Leatherland. 1992. Circadian rhythms and feeding time in fishes. Environmental Biology of Fishes, 35: 109-131.

Cabral, H. N. 2000. Comparative feeding ecology of sympatric Solea solea and $S$. senegalensis, within the nursery areas of the Tagus estuary, Portugal. Journal of Fish Biology, 57: 1550-1562.

Castro, B. M. \& L. B. Miranda. 1998. Physical oceanography of the western Atlantic continental shelf located between $4^{\circ} \mathrm{N}$ and $34^{\circ} \mathrm{S}$ - coastal segment (4,W). The Sea, 11: 209-251.

Christensen, V. \& D. Pauly. 1992. A guide to Ecopath II software system (version 2.1). Mamilia, ICLARM software 6.

Crispino, R. L. 1995. Morfologia funcional dos Teleostei: Etropus longimanus (Norman, 1933) Bothidae; Eucinostomus argenteus (Baird and Girard, 1854) Gerreidae; Orthopristis ruber (Cuvier, 1830) Haemulidae; Trachurus lathami (Nichols, 1920) Carangidae e Stephanolepsis hispidus (Linnaeus, 1758) Monocanthidae e sua relação com os hábitos alimentares. Unpublished Ph.D. Dissertation, Universidade de São Paulo, São Paulo. 62p.
WINTER

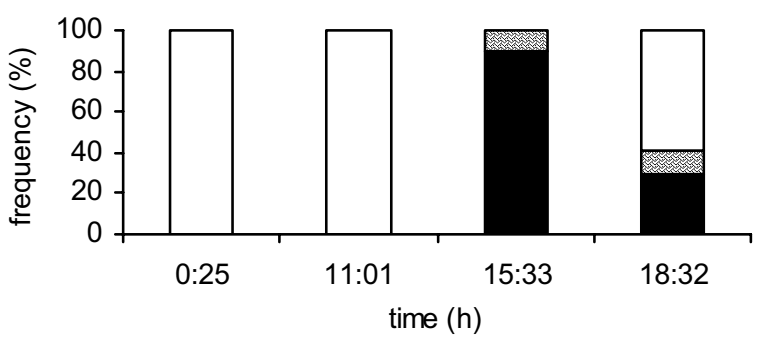

fresh partially digested $\square$ digested
SUMMER

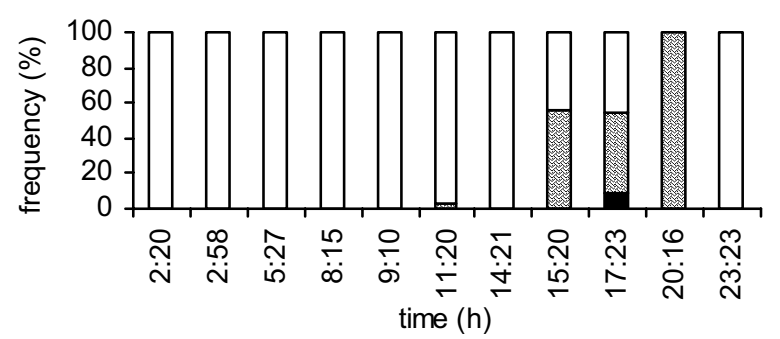

fresh partially digested $\square$ digested

Fig. 6. Proportion of the state of digestion of stomach content of Trachurus lathami by sampling period from Ubatuba shelf, in winter $\left(22-24 / 07 / 1988-23^{\circ} 35.6^{\prime} \mathrm{S} / 44^{\circ} 59^{\prime} \mathrm{W}\right)$ and summer $\left(04-06 / 12 / 1988-23^{\circ} 51.3^{\prime} \mathrm{S} / 44^{\circ} 47.6^{\prime} \mathrm{W}\right)$. 
Danemann, G. D. 1993. General characteristics of the diet of Trachinotus rhodopus (Perciformes: Carangidae). Revista de Biologia Tropical, 41(3b): 811-815.

Gerkema, M. P., J. J. Videler, J. de Wiljes, H. van Lavieren, H. Gerritsen \& M. Karel. 2000. Photic entrainment of circadian activity patterns in the tropical labrid fish Halichoeres chrysus. Chronobiology International, 17(5): 613-622.

Helmer, J. L., R. L. Teixeira \& C. Monteiro-Neto. 1995. Food habits of young Trachinotus (Pisces, Carangidae) in the inner surf-zone of a sandy beach in southeast Brazil. Atlantica. 17: 95-107.

Hernandez, S. 1999. Estudo do zooplâncton da região compreendida entre Cabo Frio (RJ) e Santos (SP), com ênfase nas espécies da família Corycaeidae (Copepoda Poecilostomatoida). Unpublished Ph.D. Dissertation, Universidade de São Paulo, São Paulo. 125p.

Hunter, J. R. 1968. Effects of light on schooling and feeding of jack mackerel Trachurus symmetricus. Journal of Fisheries Research - Board Canada, 25(2): 393-407.

Hyslop, E. J. 1980. Stomach contents analysis - a review of methods and their application. Journal of Fish Biology, 17(4): 411-429.

Kawakami, E. \& G. Vazzoler. 1980. Método gráfico e estimativa do índice alimentar aplicado no estudo de alimentação de peixes. Boletim do Instituto Oceanográfico, Universidade de São Paulo, São Paulo, 29(2): 205-207.

Linton, L. R., R.W. Davies \& F. J. Wrona. 1981. Resource utilization indices: an assessment. Journal of Animal Ecology, 50: 283-292.

Livingston, R.J. 1982. Trophic organization os fishes in a coastal seagrass system. Marine Ecological Progress Series, 7(1): 1-12.

Magurran, A. E. 1988. Ecological diversity and its measurement. Cambridge, University Press, 179p.

Manteilfel, B. P., I. I. Girsa, \& D. S. Pavlov. 1978. On rhythms of fish behaviour. Pp. 215-224. In: J. E. Thorpe (Ed.). Rhythmic Activity of fishes. London, Academic Press, 312p.

Marques, N. \& L. Menna-Barreto (orgs.). 2003. Cronobiologia: princípios e aplicações. São Paulo, EDUSP, 435p.

Mcfarland, W. N. 1986. Light in the sea - correlations with behaviors of fishes and invertebrates. American Zoologist, 26: 389-401.

Mello, R. M., J. P. Castello \& K. M. Freire. 1992. Asociacion de especies pelagicas en el sur de Brasil durante inverno y primavera. Frente Maritimo, 11(Sec.A): 63-69.

Menezes, N. A. \& J. L. Figueiredo. 1980. Manual de peixes marinhos do sudeste do Brasil. IV. Teleostei (3). São Paulo, Museu de Zoologia da Universidade de São Paulo, 96p.

Neilson, J. D. \& R. I. Perry. 1990. Diel vertical migrations of marine fishes: an obligate facultative process? Advances in Marine Biology, 26: 115-168.

Oliveira, M. R. 1999. Zooplâncton da plataforma continental sudeste do Brasil, entre Mongaguá-SP (24 $05^{\prime}$ S) e o Cabo de Santa Marta Grande-SC (28 40'S), com especial referência aos copépodos Eucalanidae. Unpublished Ph.D. Dissertation, Universidade de São Paulo, São Paulo. 147p.
Pedreira, M. M. 1997. Alimentação e hábito alimentar de larvas de Trachurus lathami (família Carangidae), na região de Ubatuba, Estado de São Paulo. Unpublished Ph.D. Dissertation, Universidade de São Paulo, São Paulo. 129p.

Pillar, S. C. \& M. Barange. 1998. Feeding habits, daily ration and vertical migration of the Cape horse mackerel off South Africa. South African Journal of Marine Science, 19: 263-274.

Pinkas, L. 1971. Food habits study. Fishery Bulletin, 152: 5-10.

Pires-Vanin, A M. S. \& Y. Matsuura. 1993. Estrutura e função do ecossistema da plataforma continental da região de Ubatuba, Estado de São Paulo: Uma introdução. Publicação Especial do Instituto Oceanográfico, Universidade de São Paulo. São Paulo, 1: 1-8.

Saccardo, S. A. 1987. Morfologia, distribuição e abundância de Trachurus lathami Nichols, 1920 (Teleostei: Carangidae) na região sudeste-sul do Brasil. Boletim do Instituto Oceanográfico, Universidade deSão Paulo, São Paulo, 35(1): 65-95.

Saccardo, S. A. \& M. Katsuragawa. 1995. Biology of the rough scad Trachurus lathami, on the southeastern coast of Brazil. Scientia Marina, 59(3-4): 265-277.

Sánchez-Vázquez, F. J., J. A. Madrid, S. Zamora \& M. Tabata. 1997. Feeding entrainment of locomotor activity rhythms in the goldfish is mediate by a feeding-entrainable circadian oscillator. Journal of Comparative Physiology. A, 181: 121-132.

Santos, M. F. L. 1992. Aspectos ecológicos de Cumacea (Crustacea, Peracarida) da região de Ubatuba, litoral norte do Estado de São Paulo-Brasil. Unpublished Ph.D. Dissertation, Universidade de São Paulo, São Paulo. 151p.

Santos, M. F. L. \& A. M. S. Pires-Vanin. 1999. The Cumacea community of the southeastern Brazilian continental shelf: structure and dynamics. Scientia Marina, 63(1): 15-25.

Shuntov, V. P. 1969. Some features of the ecology. Journal of Ichthyology, 9: 801-809.

Soares, L. S. H. \& R. Apelbaum. 1994. Atividade alimentar diária da cabrinha Prionotus punctatus (Teleostei: Triglidae) do litoral de Ubatuba, Brasil. Boletim do Instituto Oceanográfico, Universidade de São Paulo, São Paulo, 42(1/2): 85-98.

Suda, Y., T. Machii \& H. Orrego. 1995. Some fishery and biological aspects of jack mackerels, genus Trachurus (Carangidae). Scientia Marina, 59(3-4): 571-580.

Vega-Pérez, L. A. 1993. Estudo do zooplâncton da região de Ubatuba, estado de São Paulo. Publicação Especial do Instituto Oceanográfico, Universidade de São Paulo, São Paulo, 10: 65-84.

Wallace, R.K., Jr. 1981. An assesment of diet overlad indices. Transaction of American Fisheries Society, 110: 72-76.

Wootton, R. J. 1990. Ecology of teleost fishes. London, Chapman \& Hall, 404p.

Zar, J. H. 1996. Biostatistical analysis. $3^{\text {rd }}$ ed., New Jersey, Prentice Hall, 662p.

Submitted November 2005

Accepted November 2006 